for sale by any of the international suppliers, including processed and unprocessed preparations, and solid radiation sources for particular purposes. The second part deals with chemical compounds labelled with carbon-14, tritium, iodine-131, phosphorus-32 and sulphur-35. The isotopes and their compounds are listed alphabetically, and brief technical and commercial data are given for each item.

It is claimed that these volumes are comprehensive. They certainly give extensive coverage of this sub. ject : there are listed some 185 different isotopes, a very large number of labelled compounds, including more than one thousand for carbon-14 alone, and referenee is made to forty-four suppliers, being either national or commercial enterprises and operating in about a dozen different countries. For current prices (those in the Directory are no later than 1958) and fuller tochnical information it will still be necessary for users to consult the suppliers directly; but as a directory this publication will undoubtedly be most useful, and it makes plain the very great resources of radioisotopes and radioactive sources which are now readily available to all who are able to profit by their use.

\section{Treatment of Injured and Regenerating Muscles with Plant Extracts}

IN recent years, many research workers in Czechoslovakia and elsewhere have examined the use of extracts from higher plants and have studied their effect not only on micro-organisms, but also on macro-organisms (Folio Biologica (Praha), 5, No. 6 ; 1959). Soviet authors in particular have studied the possibilities of influencing healing processes with these extracts, since they contain phytoncides, substances which, in addition to bacteriostatic and bactericidal properties, are also capable of stimulating healing processes in injured tissues or organisms. Certain phytoncidal substances found, for example, in onion or garlic extracts, stimulates legeneration processes and markedly accelerate the healing of wounds. The successful results obtained by some investigators with the use of plant extracts in wound-healing stimulated S. Hoja and J. Vittek to make an experimental study of the effect of these substances on the course of regeneration processes in injured and transplanted muscles. Parsnip, fir, garlic and onion extracts were injected over long periods into injured and transplanted striated muscle in rabbits, and their effect on morphological processes in the muscle was studied. Not one of the test substances was found to stimulate regeneration of the muscles.

\section{New Record Low Sea-level Air Pressure}

A PRESSURE at sea-level of $877 \mathrm{mb}$. (25.91 in mercury) was recorded by a radiosonde dropped from a U.S. Air Force Weather reconnaissance aircraft into the eye of a typhoon in the western Pacific near Guam on September 24, 1958. The previous lowest value was $886.7 \mathrm{mb}$. $(26.185 \mathrm{in}$.) observed on a ship in a typhoon in 1927. Full details of the observation including reasons for believing the value to be accurate to within $4 \mathrm{mb}$. are given in an article by C. L. Jordan in the Monthly Weather Review for September 1959. Sea-level pressures below $900 \mathrm{mb}$. have been observed in seven other typhoons in the past eight years. The normal value of pressure at sea level is $1,013 \mathrm{mb}$. and a pressure of $877 \mathrm{mb}$. occurs normally at a height of about $3,700 \mathrm{ft}$.

\section{Gordon Research Conferences, 1960}

Every Sunday, from June 12 until August 28 inclusive, a similar seene will be enacted in three residential schools in New Hampshire, when about a hundred scientists will be arriving to register their attendance at a Gordon Research Conference. From Monday morning until Friday midday they will take part in morning and evening sessions in which a very few lectures and much discussion will take place under very friendly, relaxed and informal conditions. The discussions will be wide-ranging and profound. many new ideas and facts will be freely exchanged, because each participant knows that any information which he divulges will not be used without his specific authorization and that no written records will be kept. These conferences are among the most suecess ful and enjoyable which have yet been organized. They are held in great esteem, requests for attendance always greatly exceed the number of places and different gxoups compete keenly to have their subject as one of those selected for one of the conferences. European scientists are now showing signs of paying the Gordon Conference organizers the compliment of trying to organize conferences along similar lines in Europe. Radiation chemists organized the Miller Conference in 1959 and polymer chemists hope to hold their first conference in 1961.

The topics of the thirty-six Gordon Research conferences to be held this summer are still mainly chemical, and are either of long-term importance (such as corrosion, catalysis, inorganic chemistry) or represent growing points in the subject (such as high-pressure research, high-temperature chemistry). Full details of dates, topics, costs, registration and reservations for this year's conferences can be obtained from Dr. W. George Parks, Department of Chemistry, University of Rhode Island, Kingston, R.I., U.S.A.

\section{Lederle Medical Student Fellowships}

The Lederle Laboratories Division of the American Cyanamid Co. announces that it is making available fellowships to medical schools throughout the United States and Canada for the year 1960. These fellowships, in amounts not exceeding 600 dollars a year for any one individual, are intended to relieve in part the financial burden of students who desire to devote their summer vacations to research in the preclinical departments. Students who apply for Lederle Medical Student Research Fellowships must have the consent of the faculty member under whose supervision their research is to be conducted. Further information can be obtained from the Lederle Laboratories, American Cyanamid Co., Pearl River, New York.

\section{Carlsberg-Wellcome Travelling Research Fellow- ships}

Applications are invited for the Carlsberg Wellcome Travelling Research Fellowships, 1960-61, the object of which is to encourage co-operation, on an exchange basis, between Danish and British research workers in any branch of the natural sciences which has a bearing upon human and animal medicine. One Fellowship annually is awarded to a candidate from the United Kingdom for a year's work in Denmark and one annually to a Danish candidate for a year's work in the United Kingdom. The stipend may range from $£ 900$ to $£ 1,300$ per annum (or the equivalent sums in Danish kroner), travelling and some incidental expenses being provided in addition. 